\title{
Spatial-Temporal Variations in January Precipitation over the Period of 1950-2000 in Pakistan and Possible Links with Global Teleconnections: Geographical Perspective
}

\author{
Iftikhar Ahmad1*, Romana Ambreen', Shahzad Sultan'2, Zhaobo Sun ${ }^{3}$, Weitao Deng ${ }^{3}$ \\ ${ }^{1}$ Department of Geography, University of Balochistan, Quetta, Pakistan \\ ${ }^{2}$ Pakistan Meteorological Department, Islamabad, \& Institute of Space and Earth Information Science, Chinese \\ University of Hong Kong, Hong Kong, China \\ ${ }^{3}$ Key Laboratory of Meteorological Disaster, Ministry of Education, Nanjing University of Information Science \& \\ Technology, Nanjing, China \\ Email: ${ }^{\text {iftigeog@gmail.com }}$
}

Received 20 May 2014; revised 19 June 2014; accepted 30 June 2014

Copyright (C) 2014 by authors and Scientific Research Publishing Inc.

This work is licensed under the Creative Commons Attribution International License (CC BY). http://creativecommons.org/licenses/by/4.0/

\section{(c) (i) Open Access}

\section{Abstract}

Empirical Orthogonal Function (EOF) was performed to investigate spatial variation in January precipitation over Pakistan using ground observed mean monthly precipitation data from 19502000 with a combination of gridded reanalysis data of sea level pressure (SLP) and 500 hPa geopotential height. The leading EOF mode captures $37.51 \%$ of the total variance and the spatialtemporal variability of January precipitation was consistent in the study area. The temporal changes explicate non-periodic interannual variability and some tacit interdecadal variation. The anomalous condition is more prominent along the western bordering mountains and northern high mountainous region than any other region of Pakistan. Based on results the study reveals spatial-temporal variation in January precipitation and possible links with global teleconnections located both in the proximity as well as in the remote areas from the study locus.

\section{Keywords}

Pakistan, January Precipitation, EOF Analysis, Spatial-Temporal Variability

\footnotetext{
${ }^{*}$ Corresponding author.
} 


\section{Introduction}

The Fourth Assessment Report of IPCC [1] projects that climate variability will further aggravate floods and droughts in Asia and will increase vulnerability of poor Asian community. Side by side, the alarming rate of melting glaciers in Himalayas will have negative repercussions on water supplies in coming years [2]. The northern Pakistan accumulates substantial amount of snow during winter precipitation, which is seasonal addition to already existing glaciers and supplement the flow of River Indus, so forecast of summer discharge in the River Indus is also connected to amount of winter precipitation received in upper catchments area [3]. The year of 1997-98 was marked by strong El Nino Southern Oscillation (ENSO); induced five years drought from 1998-2002 in the south west Asia including Pakistan [4] [5] experienced most severe drought conditions in the last 50 years. As consequence, it triggered migration in different parts of southern Pakistan especially in Balochistan Province when meteorological drought reached the degree of hydrological drought. The Sulaiman, Kirthar ranges and most of the areas at their both east and west up to the Makran area in the south are out of reach of summer monsoon rainfall in normal atmospheric condition [6]. Pakistan is located in subtropical region of south Asia with complex topography and has access to Western Disturbances (WDs), and this system of lows contributes to winter precipitation [7], further it is considered the second largest source of precipitation in Pakistan. The study [8] suggests the mechanism if trough is deeper enough over the northwestern parts of Pakistan and its surrounding in winter the moisture containing winds will rush from Arabian Sea and will contribute to the precipitation of the region. The month of January is significant as the country receives substantial winter precipitation in January. The thermodynamic impact of mountains contributes to capturing precipitation [9] hence; the western and northern parts of Pakistan receive maximum precipitation from WDs as they enter from the west associated with westerlies flow. On experimental basis, through EOF analysis, this paper assesses the January precipitation over the second half of the $20^{\text {th }}$ Century to seek regional temporal and spatial variation in Pakistan and its possible relationships with atmospheric circulation at SLP and $500 \mathrm{hPa}$ level. The EOF tool is capable of identifying the physical mechanisms, which enforce climate variability [10]. The EOFs represent the eigenvectors of the covariance matrix [11]. These vectors elucidate the maximum possible variance; the leading EOF has the potential to express maximum variance while the successive EOFs are counted for less variation respectively [12].

\section{Data and Method}

In this EOF analysis, two data sets have been utilized. The first set is comprised of ground observed mean monthly January precipitation over the period of 1950-2000, obtained from the Pakistan Meteorological Department (PMD). The 45 stations with less missing data were selected from all over the country (Figure 1(a)).

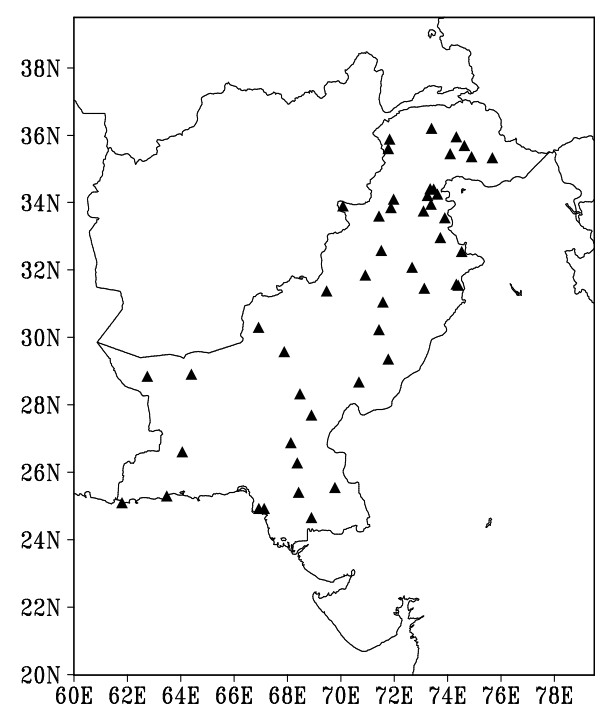

(a)

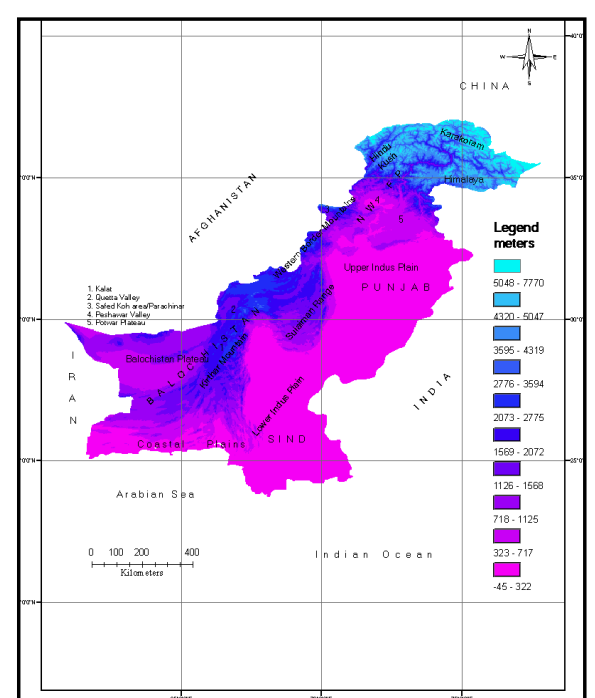

(b)

Figure 1. (a) Geographical distribution of the stations that provide data for the analysis; (b) Regional detail and landforms in Pakistan, the western and northern parts of Pakistan are dominated by rugged mountains while eastern parts of Pakistan are dominated by plains laid down by River Indus and its tributaries. 
The month of January was operated as continues time series from 1950-2000. Interpolation was done with grid resolution of $0.5^{\circ} \times 0.5^{\circ}$. The interpolation with good spatial resolution can overcome the discrepancy exists in data due to either sparsely distributed observatories or missing data. The fine spatial resolution is instrumental to point out the environmental variability in the mountainous and other diversified areas where sharp climate gradient does exist [13]. The study area covers about 796,095 $\mathrm{km}^{2}$ with distinct physiography shown in Figure 1(b) prepared from DEM input into ArcGIS.

The second set of data contains gridded reanalysis data of sea level pressure (SLP) and $500 \mathrm{hPa}$ geopotentail height (GPF) field with spatial resolution of $2.5^{\circ} \times 2.5^{\circ}$ was obtained from National Centre for Environmental Prediction/National Center for Atmospheric Research (NCEP/NCAR) at global scale over the period of 1950-2000.

The EOF provides us with statistical expressions and preferred spatial-temporal patterns of variability. Three EOFs have been performed; each set of analysis provides spatial pattern of ground variations, time series of precipitation anomalies, SLP and $500 \mathrm{hPa}$ loading anomalous patterns acknowledged by correlation coefficient for January over the period of 1950-2000 that reflect statistical significant and less significant areas.

\section{Results and Discussion}

EOF1: The leading EOF mode captured 37.51\% of the total variance. The observed spatial distribution of percentage departure of January precipitation from reference value in the time period of 1950-2000 has been shown in Figure 2(a). The anomalous spatial patterns were located as such that, a pattern was centered over Parachinar and Safed Koh about southwest of Peshawar Valley where thunderstorm frequency remains almost high in winter, another pattern was centered over the Muree Hills and contiguous Azad Jammu and Kashmir (AJK). A third pattern was centered over the Hindukush and Karakoram with parts of western Himalayas in the extreme north of the country. In addition, the pattern with less variation prevailed over southern Punjab, Sind and Balochistan provinces. The spatial variation was consistent and more obvious in northern parts of the country. The Khyberpahktoonkhwa (KPK), Federally Administered Tribal Areas (FATA) Peshawar Valley and Hindukush Karakurram Himalayas $(\mathrm{HKH})$ have comparatively steep gradient of precipitation anomaly in the study period. The internal variability is evident that the years including 1950, 1953-1954, 1957, 1959, 1961, 1964-1965, 1970, 1972-1973, 1977, 1981, 1990-1993 and 1999 had precipitation above average in Pakistan while the rest of the years of the study period have precipitation below average in January but with few years close to normal precipitation like in early 1980s. The Khyberpahktoonkhwa (KPK), Federally Administered Tribal Areas (FATA) Peshawar Valley and Hindukush Karakurram Himalayas (HKH) had comparatively steep gradient of precipitation anomalies, in this context Balochistan and Indus plains were found less significant. Overall situation derived from EOF1 reflects that the negative precipitation anomalies dominated in January over the study period. The comparison (Figure 2(b)) of average and temporal trend has been validated significantly with $r=0.92$.

The SLP and $\Phi 500 \mathrm{hPa}$ have been mapped with contour interval of 0.1, the blue color patches in the figures indicate the areas where correlation coefficient exceeds $95 \%$ significance level with respect to spatial-temporal variability of January precipitation. Reference to Figure 2(d) the Central Asia, eastern Asia, central Europe and northern Atlantic indicate significant correlation with the precipitation variability, in this connection the western tropical Pacific basin is another area of confidence level. High confidence level was achieved around the Antarctica.

The correlation pattern at $500 \mathrm{hPa}$ level (Figure 2(e)) demonstrates obvious relation especially in the middle latitudes over the Middle East extending to Central Asia and surroundings, over the eastern Asia and North America, the relation configures high confidence level. The achieved significance is high around Antarctica but not that much strong as in case of SLP.

EOF2: The EOF second mode captured $15.79 \%$ of the total variance. The time series correlation coefficient (Figure 3(b)) exhibits interannual variability quite consistently and no obvious decadal changes except in the 1950s where the precipitation was mostly found above the reference point except in northernmost lofty parts in the country. Sindh and Indus plains were characterized by less significance. The 27 years of the study period have precipitation above normal except in HKH region while 20 years faced precipitation deficit in most of the country except the $\mathrm{HKH}$ region, the rest of the years were found in the range of normal or very close to the normal precipitation.

The coefficient patterns that exhibit the relation with precipitation variability at SLP (Figure 3(c)) shows where few high significant areas were observed, area of obvious correlation exists over northern Atlantic Ocean 


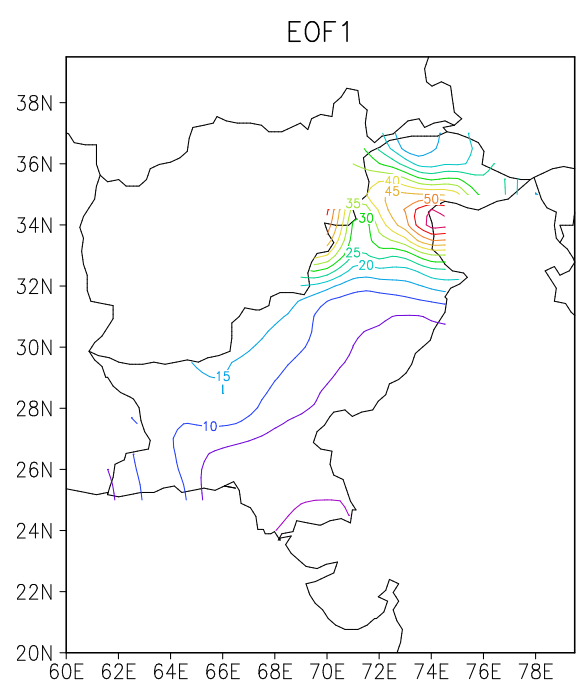

(a)

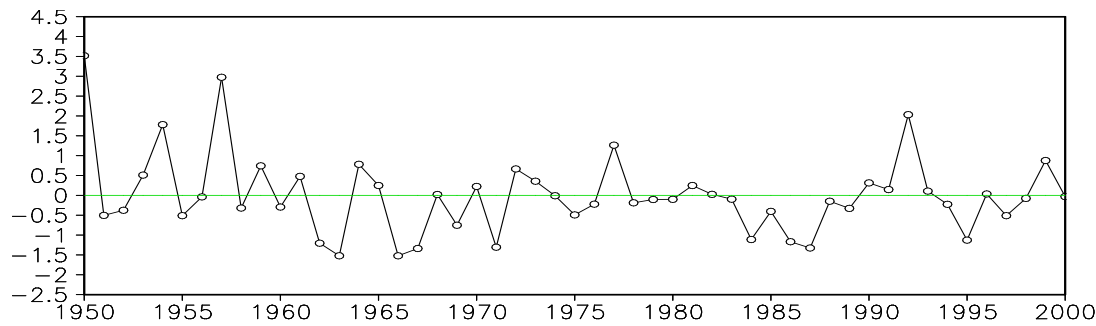

(b)

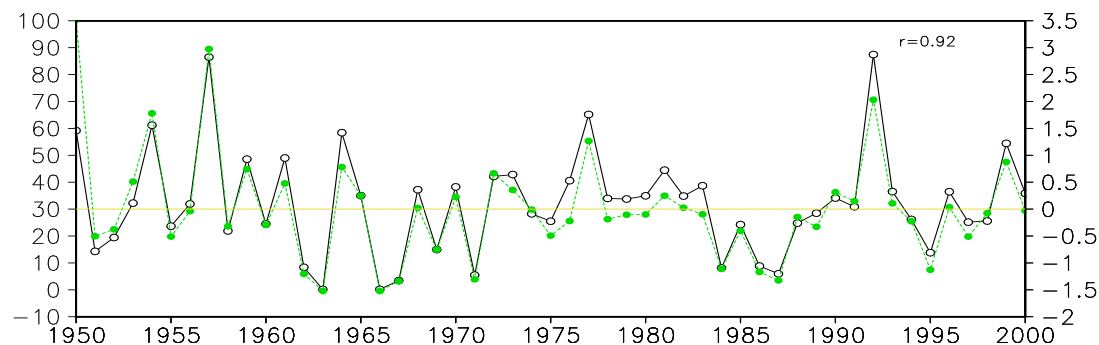

(c)

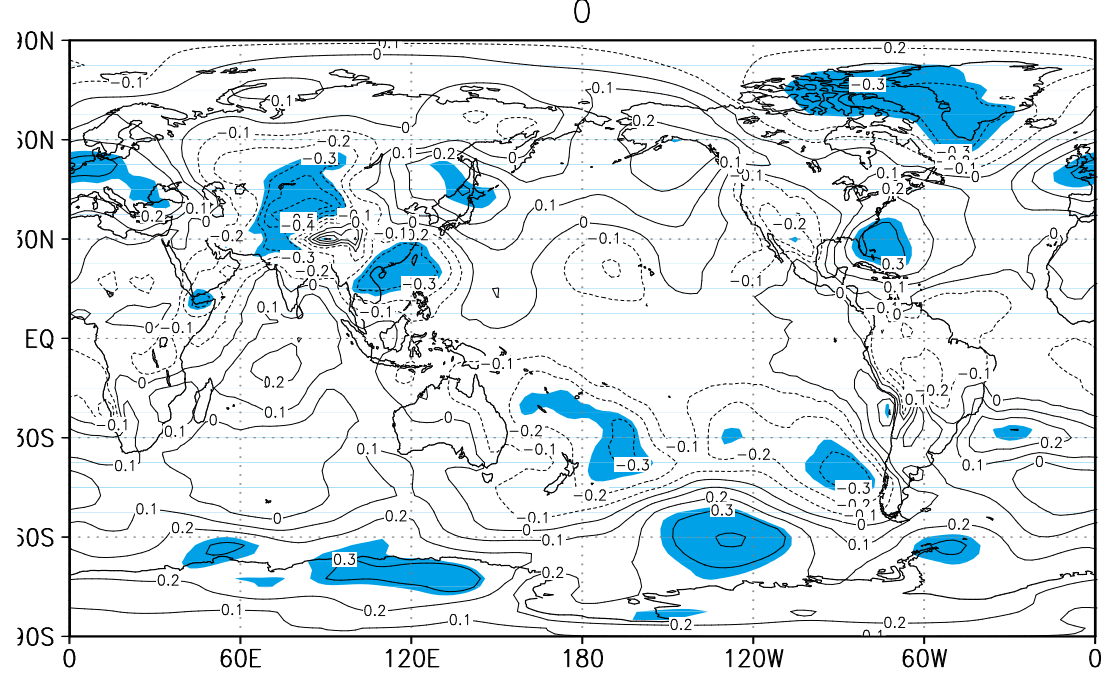

(d) 
0

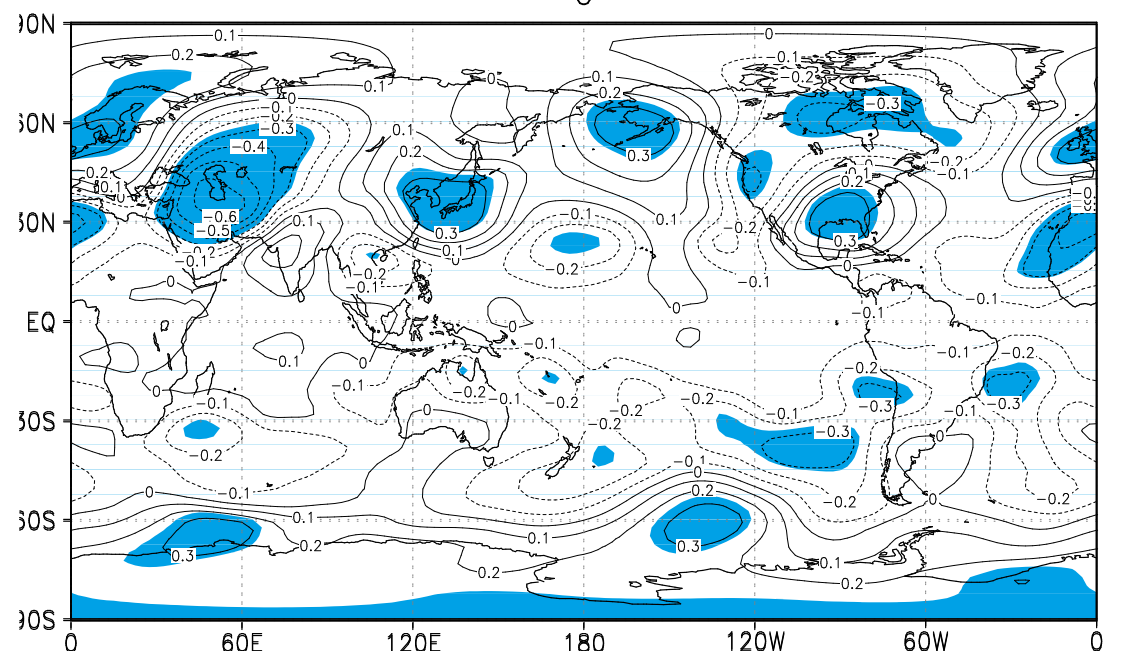

(e)

Figure 2. (a) Spatial variations in January precipitation in different areas of Pakistan reflects spatial distribution of percentage departure of January precipitation from reference value in the time period of 1950-2000; (b) Time series of the January precipitation anomalies in Pakistan (1950-2000), the interannual variability is obvious, little or no indication of decadal variability; (c) Comparison between January temporal trend (green lines) and average precipitation (black lines) over the period of 1950-2000; (d) Configuration of the high and low significant areas at SLP level at global scale in association with January precipitation anomalies observed through first mode of EOF over the period of 1950-2000; (e) The representative of global teleconnection at 500-hPa anomalous field over the period of 1950-2000 in relation to January precipitation in Pakistan.

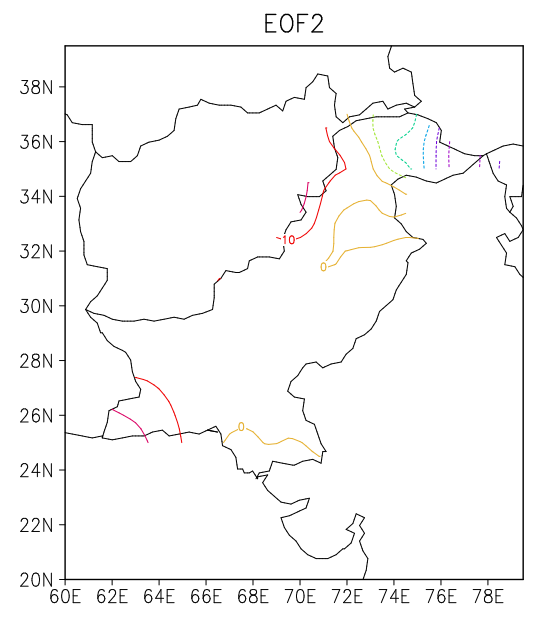

(a)

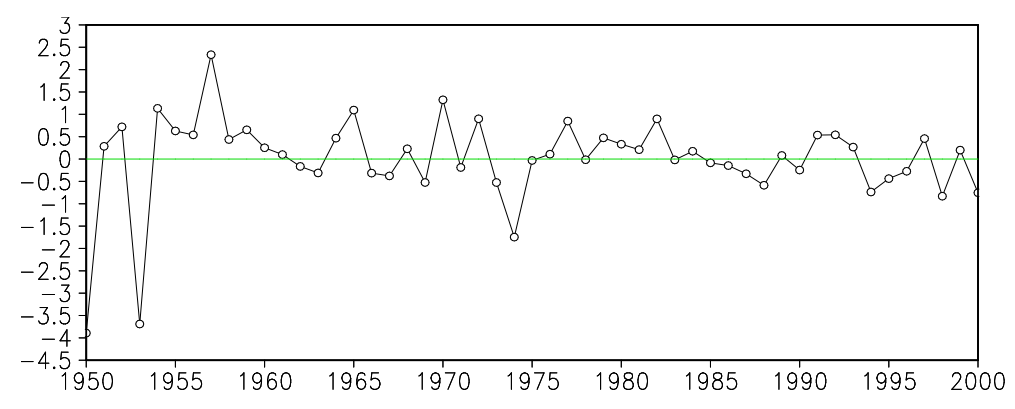

(b) 
0

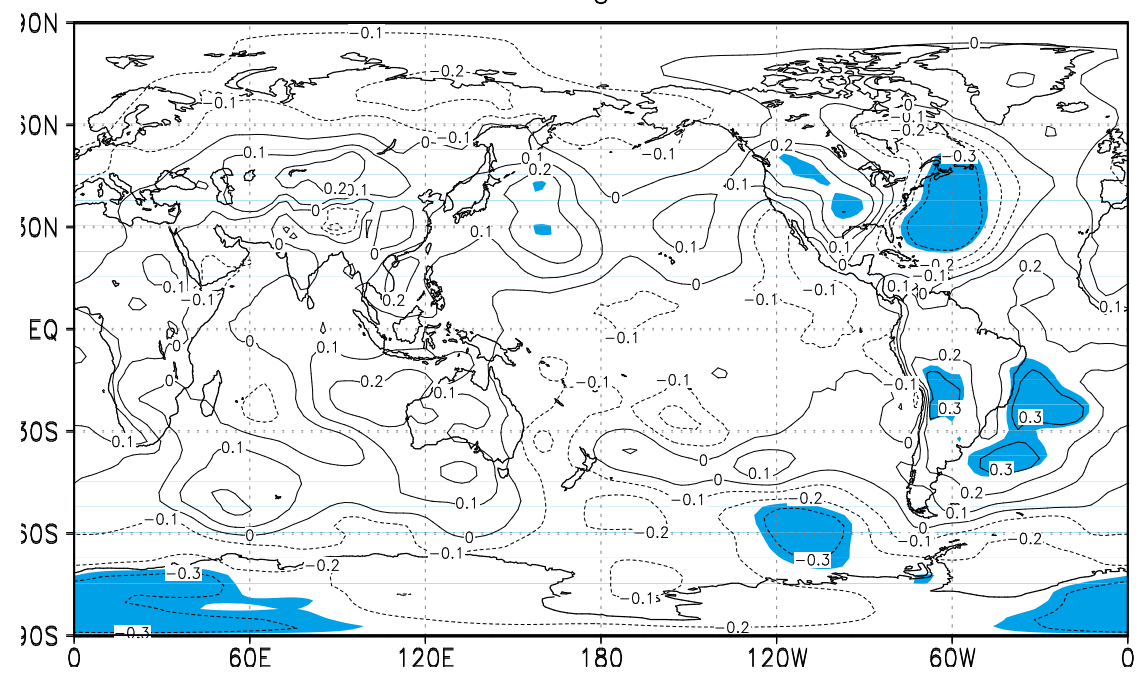

(c)

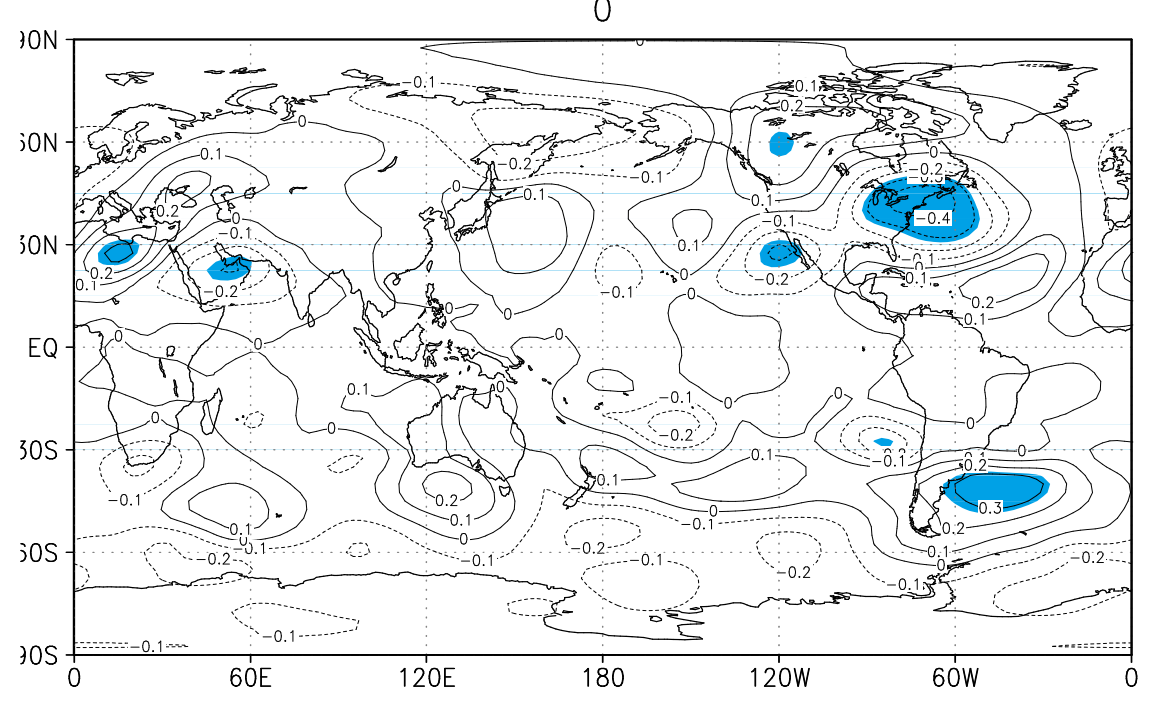

(d)

Figure 3. (a) Spatial variations in January precipitation in different areas of Pakistan over the period of 1950-2000; (b) Time series of the January precipitation displays interannual variability in Pakistan (1950-2000); (c) Configuration of the correlation coefficient at SLP at global scale in association with January precipitation anomalous condition of the study area over the period of 1950-2000 pertaining to second mode of EOF; (d) Configuration of the high and low significant areas at $500 \mathrm{hPa}$ GPH at global scale in association with precipitation variability observed in second mode of EOF over the period of 1950-2000.

that extends from tropics to the Arctic region, simultaneously the high confidence area prevailed over the tropical and subtropical western southern Atlantic basin. The considerable patches of teleconnections have been traced in the Antarctica region also. The Mediterranean, Middle East pattern centered over the Arabian Sea remained significant at $500 \mathrm{hPa}$ level. Side by side, the atmospheric state over North America and adjacent oceans configures considerable relation with observed precipitation variability. The Antarctic region in the proximity of Antarctic Circle in the southern Atlantic shows area of significance, the rest of the region around Antarctica was found less significant in this case.

EOF3: The third EOF mode captured $10.32 \%$ of the total variance. The spatial variation over Pakistan shows $(+),(-)$ and then $(+)$ patterns from south to north and reflects changes in phase structure (Figure 4(a)). The temporal correlation coefficient shows interannual variability and also some reasonable decadal changes (Figure 4(b)). 


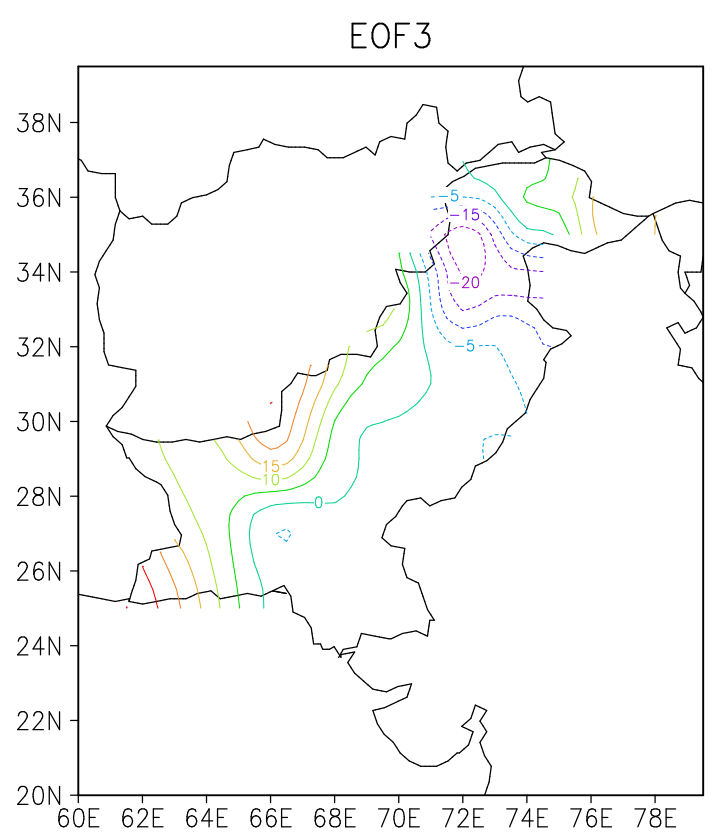

(a)

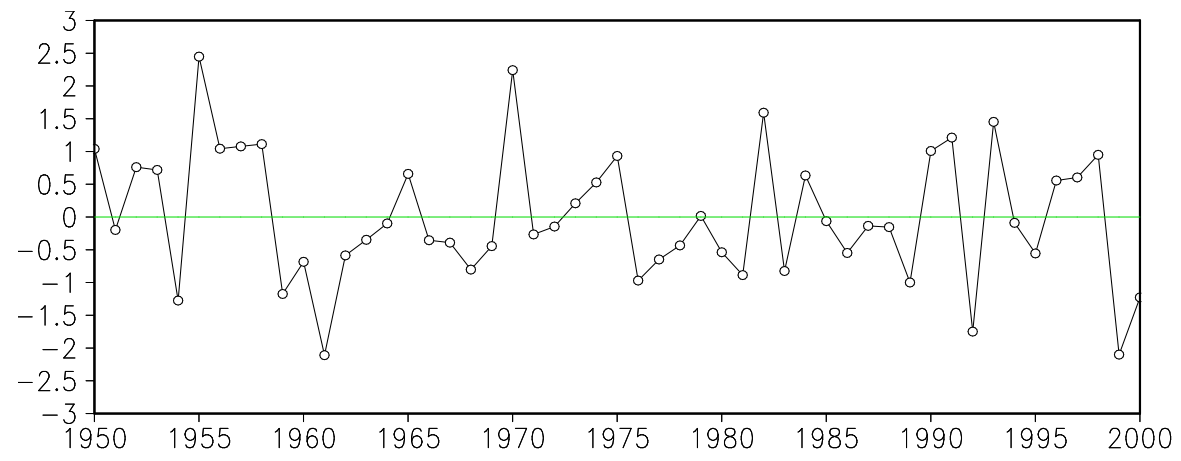

(b)

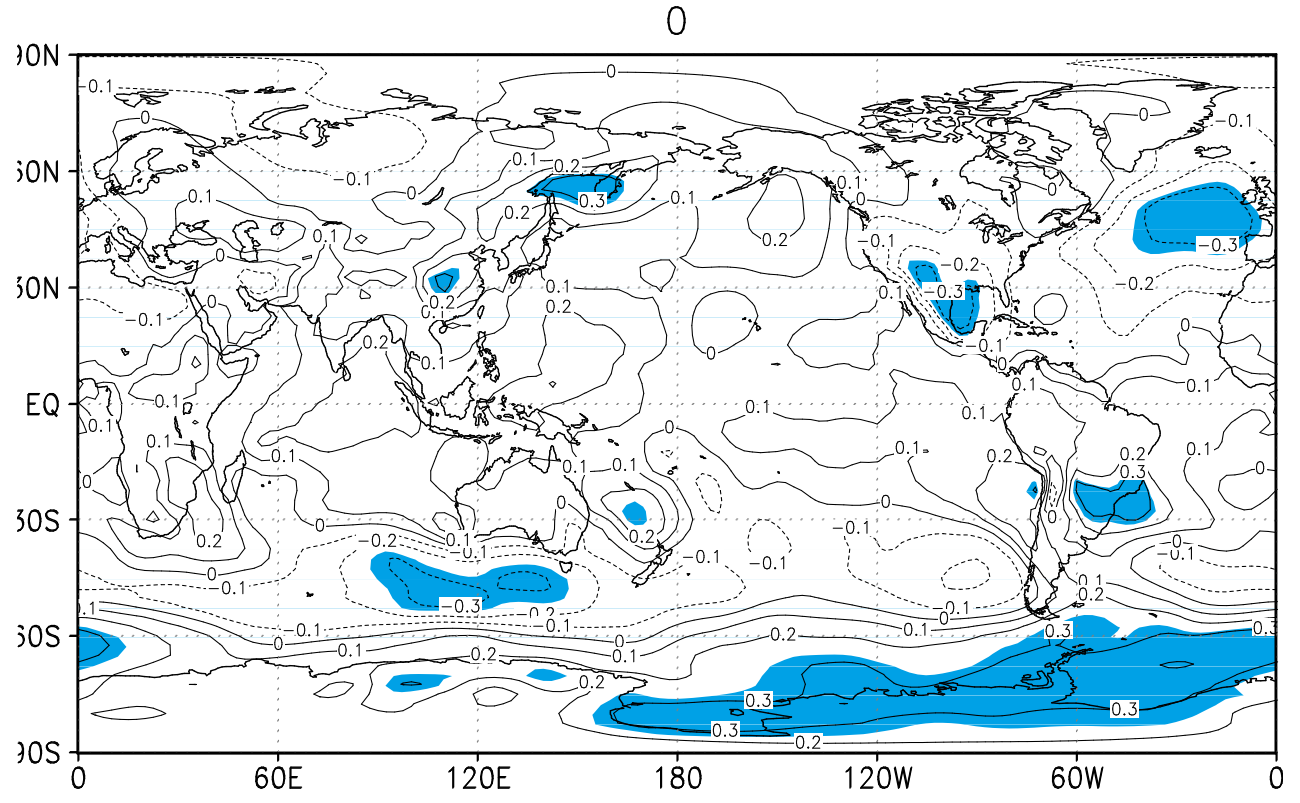

(c) 
0

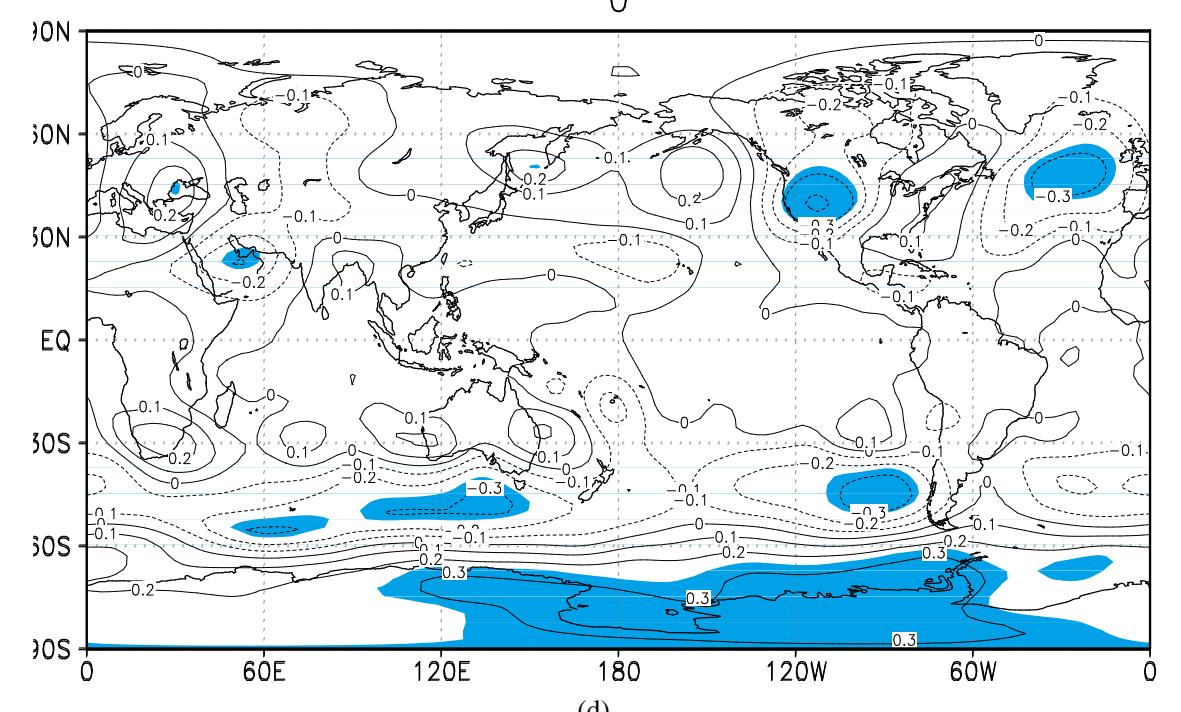

(d)

Figure 4. (a) Spatial variations in January precipitation in different areas of Pakistan over the period of 1950-2000 observed through third EOF mode; (b) Anomalous time series of the January precipitation display interannual variability in Pakistan (1950-2000); (c) Configuration of the correlation coefficient at SLP with global scale in association with January precipitation anomalies of the study area over the period of 1950-2000 pertaining to third mode of EOF; (d) Configuration of the correlation coefficient at $500 \mathrm{hPa}$ field at global scale in relation to precipitation variability observed through third mode of EOF over the period of 1950-2000.

In the decade of 1950s, mostly Pakistan had precipitation above average, in 1960s, most areas were found with deficit in precipitation and the same was true for 1970s and 1980s, based on results the Peshawar Valley and surrounding got precipitation above normal in these decades. The 1990s have shown high internal variability and less decadal signature. Twenty years of the study period were found with above normal precipitation in most parts of the country excluding Peshawar Valley, Potwar region, Muree Area and Azad Kashmir where these months reflect precipitation below average. Twenty nine years were observed with rainfall below normal in most of Pakistan except Peshawar Valley, Potwar region, Muree Area and Azad Kashmir. The above said spatial-temporal variability in January precipitation has shown link with the atmospheric state at SLP (Figure 4(c)) in Atlantic Ocean including Mediterranean area, other regions of high significance were eastern Asia and Antarctic areas as well. The precipitation variability also has shown relation with anomalous condition of atmosphere at 500 hPa (Figure 4(d)), the relation over Mediterranean, Middle East, North America, northern basin of Atlantic Ocean and Antarctic and surrounding areas was quite strong.

The climate variability in Pakistan and surroundings has been linked with North Atlantic Oscillations (NAO) as documented by various researchers e.g. [14]-[17]. The positive signature of winter precipitation in northern rugged parts of Pakistan has association with positive (NAO) index [18]. According the findings the Mediterranean region and North Atlantic Ocean are the two most prominent areas at both SLP and $500 \mathrm{hPa}$, which show their influence on the study area through teleconnection. Based on results, teleconnection support that the January precipitation and its variation in Pakistan have deep link with NAO and pressure system over the Mediterranean. The $500 \mathrm{hPa}$ field is generally used to determine the prevailing atmospheric condition from middle to upper troposphere, the planetary waves and their transient behavior have been traced, to be associated with westerlies flow [19] and has been recognized as East Atlantic and West Atlantic patterns pertaining to NAO [20]. Results and the above discussion lead us to the conclusion that the variability of January precipitation in Pakistan has been originated from the atmospheric state over the north Atlantic, Mediterranean and surrounding regions.

\section{Conclusions}

Based on results the rugged northern and western parts of the country show significant sptial-tempotral precipitation variability in Pakistan. These areas include Kalat region, Quetta Valley, western Bordering Ranges, KPK and across Peshawar Valley to the northwestern lofty mountains up to the Karakoram Ranges in the extreme 
north of the country. The observed spatial-temporal variability in relation to anomalous atmospheric states at SLP and $500 \mathrm{hPa}$ fields supports that precipitation variability in January can be connected to highly variable nature of westerlies. The interannual variability was salient feature in all modes and found consistently throughout time series of precipitation anomalies. The leading EOF mode 1 depicts correlation pattern at SLP and $500 \mathrm{hPa}$ height field could be the acknowledgment of deep trough over the region, which encourages precipitation in winter. The interdecadal changes were not clear in the first two EOF modes but reasonable interdecadal changes were observed associated with EOF mode 3.

The NAO pressure system is known for its high variability, the WDs are mostly nurtured by this system, thus in this way have indispensable influence on the variability of precipitation in north and northwestern parts of the country. The results also lead us to the assumption that the precipitation variability under discussion had link with remote atmospheric condition round Antarctic region that needs further scientific investigation especially at $700 \mathrm{hPa}$ field. We have put forward the January precipitation variability with regional detail in Pakistan; this geographical approach could be the potential base line study for further scientific investigation.

\section{Acknowledgements}

We are grateful to the PMD for provision of ground observed data. We are thankful to the anonymous reviewers as their comments and suggestions improved the paper substantially. We are highly grateful to the NCEP/ ANCAR for making the data available.

\section{References}

[1] Solomon, S., Qin, D., Manning, M., Chen, Z., Marquis, M., Averyt, K.B., Tignor, M. and Miller, H.L., Eds., IPCC (2007) Climate Change 2007: The Physical Science Basis. Contribution of Working Group I to the Fourth Assessment. Report of the Intergovernmental Panel on Climate Change. Cambridge University Press, Cambridge, New York, 996 p.

[2] Bernett, T.P., Adam, J.C. and Lettenmaier, D.P. (2005) Potential Impacts of a Warming Climate on Water Availability in a Snow-Dominated Region. Nature, 438, 303-309. http://dx.doi.org/10.1038/nature04141

[3] Archer David, R. and Fowler Haley, J. (2004) Spatial and Temporal Variations in Precipitation in the Upper Indus Basin, Global Teleconnections and Hydrological Implications. Hydrology and Earth System Sciences, 8, 47-61. http://dx.doi.org/10.5194/hess-8-47-2004

[4] Barlow, M., Cullen, H. and Lyon, B. (2002) Drought in Central and Southwest Asia: La Nina, the Warm Pool, and Indian Ocean Precipitation. Journal of Climate, 15, 697-700. http://dx.doi.org/10.1175/1520-0442(2002)015<0697:DICASA>2.0.CO;2

[5] Rasul, G., Qin, D. and Chaudhry, Q.Z. (2008) Global Warming and Melting Glaciers along Southern Slopes of HKH Ranges. Pakistan Journal of Meteorology, 5, 63-76.

[6] Pant, G.B. and Kumar, K.R. (1997) Climates of South Asia. John, Willy and Sons, England, 6.

[7] Syed, F.S., Giorgi, F., Pal, J.S. and Keay, K. (2009) Regional Climate Model Simulation of Winter Climate over Central-Southwest Asia, with Emphasis on NAO and ENSO Effects. International Journal of Climatology, 30, 220-235. http://dx.doi.org/10.1002/joc.1887

[8] Syed, F.S., Giorgi, F., Pal, J.S. and King, M.P. (2006) Effect of Remote Forcings on the Winter Precipitation of Central Southwest Asia Part 1: Observations. Theoretical and Applied Climatology, 86, 147-160. http://dx.doi.org/10.1007/s00704-005-0217-1

[9] Dimiri, A.P. (2006) Surface and Upper Air Fields during Extreme Winter Precipitation over the Western Himalayas. Pure and Applied Geophysics, 163, 1679-1698.

[10] Dommenget, D. and Latif, M. (2002) Notes and Correspondence: A Cautionary Note on the Interpretation of EOFs, Journal of Climate, 15, 216-225. http://dx.doi.org/10.1175/1520-0442(2002)015<0216:ACNOTI>2.0.CO;2

[11] Jolliffe, I.T. (1986) Principal Component Analysis. Springer-Verlag, New York, 290 p. http://dx.doi.org/10.1007/978-1-4757-1904-8

[12] Ambaum, M.H.P., Hoskins, B.J. and Stephenson, D.B. (2001) Arctic Oscillation or North Atlantic Oscillation. Journal of Climate, 14, 3495-3507. http://dx.doi.org/10.1175/1520-0442(2001)014<3495:AOONAO>2.0.CO;2

[13] Hijmans, R.J., Camerone, S.E., Parra, J.L., Jones, P.G. and Jarvis, A. (2005) Very High Resolution Interpolated Climate Surfaces for Global Land Areas. International Journal of Climatology, 25, 1965-1978. http://dx.doi.org/10.1002/joc.1276

[14] Archer, D.R. and Fowler, H.J. (2004) Spatial and Temporal Variations in Precipitation in the Upper Indus Basin, 
Global Teleconnections and Hydrological Implications. Hydrology and Earth System Sciences, 8, 47-61. http://dx.doi.org/10.5194/hess-8-47-2004

[15] Rao, Y.P. (1981) The Climate of the Indian Sub-Continent. In: World Survey of Climatology, Vol. 9, Climates of Southern and Western Asia, Elsevier, Amsterdam, 67-182.

[16] Fowler, H.J. and Archer, D.R. (2006) Conflicting Signals of Climatic Change in the Upper Indus Basin. Journal of Climate, 19, 4276-4293. http://dx.doi.org/10.1175/JCLI3860.1

[17] Snead, E.R. (1968) Weather Patterns in Southern West Pakistan. Archiv für Meteorologie, Geophysik und Bioklimatologie, Serie B, 16, 316-346.

[18] Syed, F.S., Giorgi, F., Pal, J.S. and Keay, K. (2010) Regional Climate Model Simulation of Winter Climate over Central-Southwest Asia, with Emphasis on NAO and ENSO Effects. International Journal of Climatology, 30, 220-235. http://dx.doi.org/10.1002/joc.1887

[19] Wallace, J.M. and Gutzler, D.S. (1980) Teleconnections in the Geopotential Height Field during the Northern Hemisphere Winter. Monthly Weather Review, 109, 784-812.

[20] Wallace, J.M. and Gutzler, D.S. (1981) Teleconnections in the Geopotential Height Field during the Northern Hemisphere Winter. Monthly Weather Review, 109, 784-812. http://dx.doi.org/10.1175/1520-0493(1981)109<0784:TITGHF>2.0.CO;2 
Scientific Research Publishing (SCIRP) is one of the largest Open Access journal publishers. It is currently publishing more than 200 open access, online, peer-reviewed journals covering a wide range of academic disciplines. SCIRP serves the worldwide academic communities and contributes to the progress and application of science with its publication.

Other selected journals from SCIRP are listed as below. Submit your manuscript to us via either submit@scirp.org or Online Submission Portal.
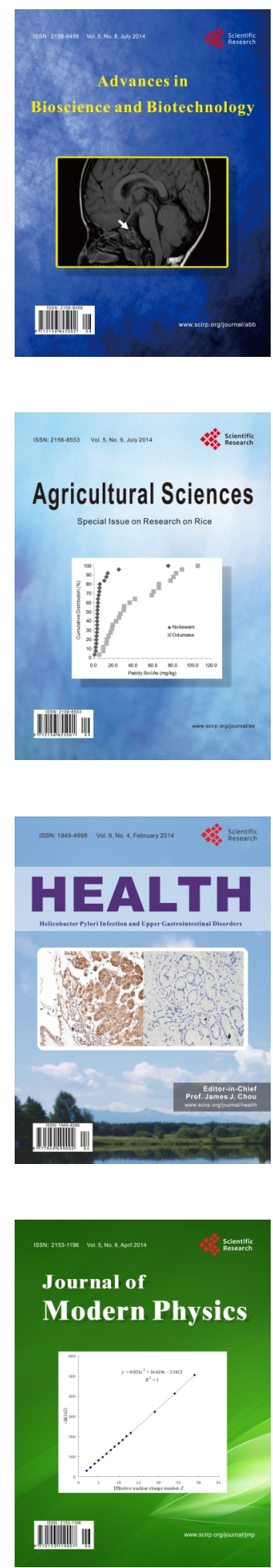
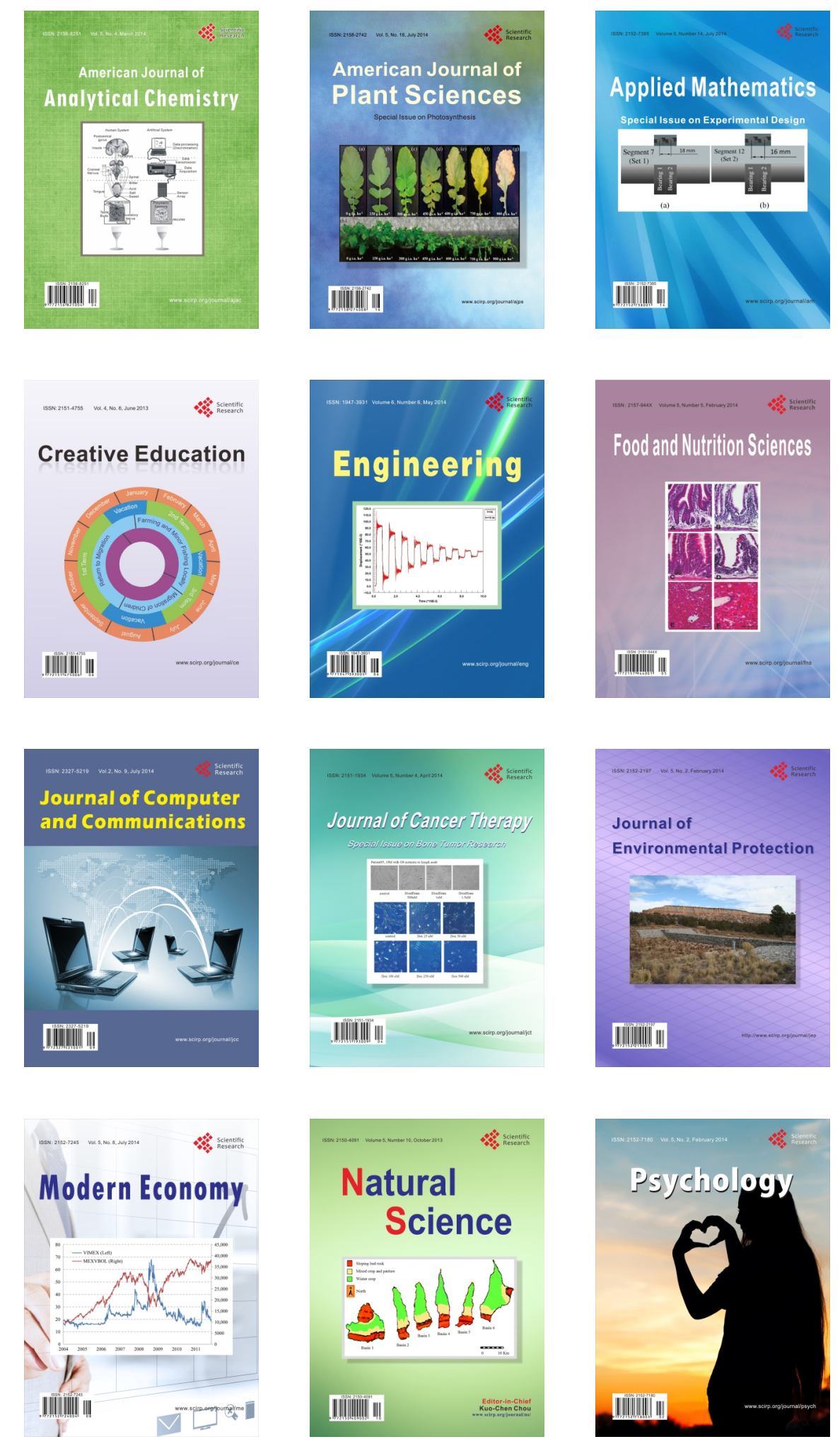